ISO 9001:2008 Certified

International Journal of Engineering and Innovative Technology (IJEIT)

Volume 10, Issue 2, August 2020

\title{
A PVPS/BS Based Induction Motor Drive in Water Pumping System Comparative Study
}

\author{
E. A. El-Sayed and M. A. ELqarni
}

Electrical Engineering Dept., College of Engineering, University of Business and Technology (UBT)

\begin{abstract}
One of the most important applications of PVPS is the operation of electric motors. This paper introduced a complete study of the impact of PVPS solar cell type on the induction motor (IM) performance. Different types of $P V$ solar cells have been selected. Moreover, the application has been carried out for five different types of 1-phase and 3-phase IM. The design procedure takes into account the nature of the PVPS output voltage as well as the requirements of the IM at different operating conditions such as starting, loading ratio and normal operation. The energy cost figure (ECF) (the price per produced kWh) has been calculated for such cases taking into consideration the different solar cell types as well as the different IM types. In addition a deep comparative study has been carried out to determine the optimum solution of operating IM pumping system fed by PVPS. Finally, This paper provides a contribution of the PVPS modeling and its characteristics, studies the combination of PVPS/Battery Storage (PVPS/BS/IM system) and at the last investigates the economic analysis of ECF.
\end{abstract}

\section{Index Terms-BS, IM, PVPS}

\section{INTRODUCTION}

Photovoltaic power systems have been proven capable of operating efficiently in a wide range of applications including small, low-power devices for remote communications equipment, medium as well as large size systems. For example, the use of PVPS energy for autonomous systems has been shown temperature of the cell, $\mathrm{T}_{\mathrm{r}}$ is the reference temperature of the cell, to be attractive because of its low cost [1]. In isolated region, $\mathrm{T}_{\mathrm{a}}$ is the ambient temperature, $\mathrm{H}_{\text {th }}$ is the hourly radiation on the PVPS pumps are cheaper than standard diesel pumps [2].

\section{METHODOLOGY}

The design of PVPS includes the calculations of the required solar cells area, no of modules to satisfy the requirements of the load power, voltage and current. This can be carried out by the po following algorithm.

\section{Computation of monthly best tilt angle}

Where:

$23.45 \sin (360(284+n) / 365)$, Where $\mathrm{n}$ is the day of the $\mathrm{y}$ year given for each month [3], $S$ is the tilt angle in degree, $\emptyset$ is the latitude angle in degrees and $\delta$ is the solar declination angle.

Calculation of the radiation on the tilted surfaces [4]

$$
\begin{aligned}
& K_{\mathrm{t}}=\bar{H} / \bar{H}_{0} \\
& \overline{H_{\mathrm{t}}}=\bar{R} * \bar{H}=\bar{R} * K_{\mathrm{t}} * \overline{H_{0}} \\
& \bar{R}=\left(\frac{1-\bar{H}_{d}}{\bar{H}}\right) R_{b}+\left(\frac{\bar{H}_{d}}{\bar{H}}\right)\left(\frac{1+\cos S}{2}\right)+\rho\left(\frac{1-\cos S}{2}\right) \\
& \overline{H_{d}}=1.39-4.027 \bar{K}_{\mathrm{t}}+5.531 \bar{K}_{\mathrm{t}}^{2}-3.108 \bar{K}_{\mathrm{t}}^{\mathrm{a}}
\end{aligned}
$$

$$
\begin{aligned}
& \bar{R}_{b}=\frac{\cos (\emptyset-S) \cos \sigma \sin \omega_{g 1}+(\pi / 180) \omega_{g 1} \cdot \sin (\emptyset-S) \sin \delta}{\cos \emptyset \cos \delta \sin \omega_{s}+(\pi / 180) \omega_{g} \cdot \sin \emptyset \sin \delta} \\
& \omega_{s}=\cos ^{-1}(-\tan \emptyset \tan \delta) \\
& \omega_{s 1}=\min \left[\omega_{s}, \cos ^{-1}(-\tan (\emptyset-S) \tan \delta)\right]
\end{aligned}
$$

Where:

$\bar{H}_{0}$ is the monthly average daily extraterrestrial radiation [4]. $\vec{H}$ is the monthly average daily radiation on the horizontal urface.

$\overline{H_{t}}$ is the monthly average daily radiation on the tilted surface.

$\overline{H_{d}}$ is the monthly average daily diffuse radiation. $\omega_{s}$ is the unset hour angle for a horizontal surface. $\omega_{s 1}$ is the sunset hour angle for the tilted surface.

Calculation of solar cells area [1] $\eta_{c}=\eta_{y}\left[1-0.0062\left(T_{c}-T_{y}\right)\right]$

$T_{c}=T_{a}+\left(k_{1} * H_{t h} * 100\right)$

,$S C A_{h}=\frac{\left(p_{L} * F_{s}\right)}{\left(H_{t h}^{*} \eta_{c}^{*} \eta_{t r}^{*} \eta_{p e} * V_{f}\right)}$ $S C A_{\mathbb{L}}=\sum_{t=16}^{\mathrm{t}=16} S C A_{\mathrm{h}} / 8$

$S C A_{y}=\sum_{i=1}^{i=12} S C A_{d} / 12$ Land area $=S C A y /$ Land area factor

No. of modules $=S C A y /$ module area

Where: $\eta_{c}$ is the operating efficiency of the cell, $\eta_{r}$ is the reference efficiency of the cell, $T_{c}$ is the operating tilted surface $(\mathrm{kW} / \mathrm{m} 2)$ and it has been calculated by multiplying the hourly radiation on the horizontal surfaces for each month by $\mathrm{R}$ of the that month,

$\mathrm{SCA}_{\mathrm{h}}$ is the hourly solar cells area (m2), $\mathrm{P}_{\mathrm{L}}$ is the load power, $\mathbf{F}_{\mathbf{S}}$ is the safety factor which includes an allowance for the possible inaccuracy of the insulation data (1.1), $\eta_{\mathrm{tr}}$ is the transformer efficiency (0.95), $\eta_{p c}$ is the power conditioning unit efficiency (0.95), $V_{f}$ is the variability factor which takes into account the influence of the variation of the insulation from year to year (0.95), SCA $_{d}$ is the monthly average daily solar cells area, SCA $_{y}$ is the yearly average solar cells area. The average generated power has been estimated hourly, monthly and yearly as follows:

$$
\begin{aligned}
& P_{h h}=\frac{S C A_{h} * H_{i h}^{*} \eta_{c}^{*} \eta_{p c} * \eta_{t r} * V_{f}}{F_{S}} \\
& P_{y}=\sum_{\mathrm{i}=1}^{\mathrm{i}=12} P_{\mathbb{Q}} / 12
\end{aligned}
$$

The capacity factor is defined as the ratio between the generated power and the demand power. The hourly, monthly and yearly capacity factors $P_{\mathbb{Q}}=\sum_{\mathrm{t}=9}^{\mathrm{t}=16} R_{\mathrm{h}} / 8$ are determined as follows: 
ISO 9001:2008 Certified

International Journal of Engineering and Innovative Technology (IJEIT)

Volume 10, Issue 2, August 2020

$C F_{d}=\sum_{\mathrm{t}=16}^{\mathrm{t}=16} C F_{\mathrm{h}} / 8$

$C F_{\mathrm{h}}=R_{\mathrm{h}} / P_{\mathrm{L}}$

,CF $=\sum_{i=1}^{i=12} C F_{d d} / 12$

The total energy generated by the designed solar cell array, ESA, must be exactly equal to the energy required by the load requirement of the energy, ELL, plus the energy required to recharge the battery, EB, i.e.

$E S A=E L L+E B$

If the solar array has sufficient capability, i.e. ESA > $(\mathrm{EB}+$ ELL), then the battery storage is expected to be fully charged before the end of the sunlight period. Whereas, if the solar array has insufficient output, i.e. ESA $<(E B+E L L)$, then the battery a storage would continually decrease its energy in each successive charge/discharge operation.

The PVPS voltage and current at any radiation level can be obtained as follows [5]:

$$
\begin{aligned}
& V_{p w p s}=P_{p v o} *\left(\log H_{t h} / \log H_{n}\right) *\left[1+h_{v}\left(T_{c}-T_{0}\right)\right] \\
& I_{p w p s}=I_{\text {pvo }} *\left(\frac{H_{t h}}{H_{n}}\right) *\left[1+h_{v}\left(T_{c}-T_{0}\right)\right]
\end{aligned}
$$

Where: Ppvps, Ipvps are the voltage and current of the PVPS at any radiation $\mathrm{H}_{\text {th }} \mathrm{w} / \mathrm{m} 2$ and at the temperature Tc $(\mathrm{Co})$. Ppvo, Ipvo are the voltage and current at the normal radiation $\mathrm{Hn}\left(1000 \mathrm{~W} / \mathrm{m}^{2}\right)$. The cell temperature at normal radiation, hv, hi are parameters depending on the solar cell material and they are $-3.7 \times 10^{-3} / C^{\circ} / c o$ and $6.4 \times 10^{-4} / C^{\circ}$ respectively. $\mathrm{K} 1$ is the thermal resistance, $\mathrm{m} 2 . \mathrm{Co} / \mathrm{W}$. The current to or from the battery can be estimated as follows:

$$
A=V_{R} / V_{\text {PVPS }}, \quad \quad I_{B P}=A * I_{\text {gt }} \quad=I_{\text {PVPS }} \mp I_{B}
$$

Where: $I_{s t}$ is the induction motor starting current, $V_{\text {pvpsI }}$ is the inverter output voltage which represents the input voltage of the transformer, $\mathrm{A}$ is the transformer turns ratio, $\mathrm{V}_{\mathrm{R}}$ is $\mathrm{IM}$ rated voltage, $I_{B P}$ is the PVPS/BS combination output current, $I_{B}$ is the BS current.

By the aid of radiation, ambient temperature data during the day time along the year and the above equations (24), (25) and (26). The I-V C/C of the solar cells can be carried out as detailed in the following [5]:

$$
\begin{aligned}
& \mathrm{V}=\mathrm{f}(\mathrm{t}) \\
& V=-I * R_{g}+\left(\frac{1}{\lambda}\right) * \ln \left(\frac{I_{\mathrm{ph}}-\beta I-\left(V / R_{g h}\right)}{I_{0}}+1\right)
\end{aligned}
$$

Where: $\lambda=\frac{q}{k Z T}$,

$\mathrm{q}$ is the charge of the electron, $\mathrm{K}$ is the

Boltzmann constant, $\mathrm{T}$ is the temperature, $\mathrm{Z}$ is a correction factor, $\mathrm{I}_{\mathrm{ph}}$ is the photon current.

$$
\beta=\frac{1+R_{g}}{R_{g h}}
$$

Where: $R_{s}, R_{s h}$ are the series, shunt resistances respectively and $I_{o}$ is the diode current as shown in Fig.1.

In this section, the cost estimation procedure that has been followed to calculate the ECF for the different studied cases has been introduced.

The cost of solar cell modules, battery storage (BS), power conditioning unit (PCU), land area, the wiring and control equipment have been considered [6].

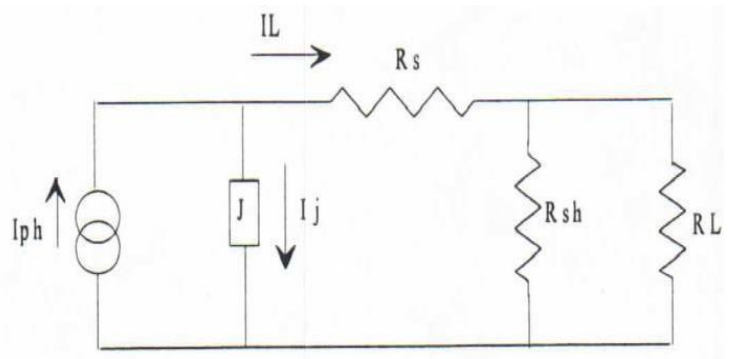

Fig. 1. The Equivalent Circuit of the Solar Cell

Total solar cell area cost $=$ TSCC $=$ SCAy $\left(\mathrm{m}^{2}\right) * \mathrm{SC}\left(\$ / \mathrm{m}^{2}\right)$ Land area $=$ SCAy/land area factor $(\mathrm{LF})$

Land cost $(\mathrm{LC})=$ land area $(\mathrm{m} 2) *$ land price $\left(\$ / \mathrm{m}^{2}\right)$ Power conditioning unit cost $(\mathrm{PCC})=$ power conditioning unit price $(\mathrm{PC}$ $\$ / \mathrm{W})^{*}$ total power in watt.

Field control wiring and building cost $(\mathrm{FC})=\$ 1005200$ Battery cost $(\mathrm{BC})=\mathrm{kWh}$ capacity $*$ price $/ \mathrm{kWh}$ of capacity $(\$ / \mathrm{kWh})$

Initial cost $(\mathrm{IC})=\mathrm{TSCC}+\mathrm{LC}+\mathrm{PCC}+\mathrm{FC}+\mathrm{BC}$ Engineering, management and installation cost is taken as $5 \%$ of the initial cost.

Capital Cost $(C C)=1.05 *$ IC Levalized annual Cost $(L A C)=F^{*} C C F=\frac{r(1+r)^{n}}{\left((1+r)^{n-1}-1\right)}$

Where: $\mathrm{N}$ is the life period taken as 30 years; $\mathrm{r}$ is the rate of interest taken as $10 \%$

Operating and maintenance Cost $(\mathrm{O} \& \mathrm{MC})=0.01 *$ LAC Total levalized Annual Cost $(\mathrm{TLAC})=\mathrm{LAC}+(\mathrm{O \& MC})$

$E C F=\frac{T L A C}{\text { Total yearly } k W h \text { generated }} \quad\left(\frac{\$}{\mathrm{kWh}}\right)$

III. CASE STUDY

The problem of operating an IM supplied by PVPS can be considered from different sides of view. In this paper we are going to investigate the combination of PVPS/BS/PCU/Transformer/ IM as shown in Fig. 2.

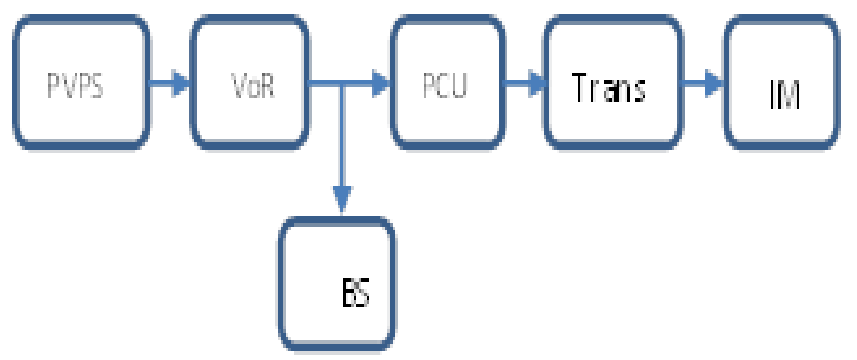

Fig. 2 Block diagram of the Proposed Combined System

The problem, focused here, appears in this combined system to be the starting current of the IM. Taking into consideration that the PVPS output voltage and current very corresponding to the variation of the solar radiation, it is necessary to use a voltage regulator (Vo.R). On the other hand, it is needed to use a BS and a tapping transformer to accomplish the IM starting current requirements. The load considered in this paper is an IM. Five different types of 1- $\phi$ and 3- $\phi$ IM have been selected. Table (1) shows the characteristics of the selected IM. 
ISSN: 2277-3754

ISO 9001:2008 Certified

International Journal of Engineering and Innovative Technology (IJEIT)

Volume 10, Issue 2, August 2020

Table 1. The Characteristics of the Selected IM

\begin{tabular}{|l|l|l|l|l|}
\hline $\begin{array}{l}\text { Item } \\
\text { Type }\end{array}$ & $\begin{array}{l}\text { No. } \\
\text { of } \\
\square\end{array}$ & $\begin{array}{l}\text { Rated } \\
\text { Power } \\
\text { (PR) }\end{array}$ & $\begin{array}{l}\text { Rated } \\
\text { Curren } \\
\text { t(IR) }\end{array}$ & $\begin{array}{l}\text { Rated } \\
\text { Voltag } \\
\text { e (VR) }\end{array}$ \\
\hline CRIM & $1-\square$ & $175 \mathrm{w}$ & $1.3 \mathrm{~A}$ & $220 \mathrm{~V}$ \\
\hline SPIM & $1-\square$ & $175 \mathrm{w}$ & $2.2 \mathrm{~A}$ & $220 \mathrm{~V}$ \\
\hline CSIM & $1-\square$ & $175 \mathrm{w}$ & $2.2 \mathrm{~A}$ & $220 \mathrm{~V}$ \\
\hline WRIM & $3-\square$ & $175 \mathrm{w}$ & $0.53 \mathrm{~A}$ & $380 \mathrm{~V}$ \\
\hline SQIM & $3-\square$ & $175 \mathrm{w}$ & $0.52 \mathrm{~A}$ & $380 \mathrm{~V}$ \\
\hline
\end{tabular}

Table 2. The Characteristics of the Selected Solar Cell Types.

\begin{tabular}{|c|c|c|c|}
\hline $\begin{array}{l}\text { Solar Cell } \\
\text { type item }\end{array}$ & $\begin{array}{l}\text { Dendritic-Web } \\
\text { silicon }\end{array}$ & $\begin{array}{l}\text { Monolithic } \\
\text { thin film } \\
\text { amorphous }\end{array}$ & $\begin{array}{l}\text { M-50 } \\
\text { silicon }\end{array}$ \\
\hline $\begin{array}{l}\text { Dimension } \\
\mathrm{s}(\mathrm{m})\end{array}$ & $1.32 \times 1.32$ & $\begin{array}{l}1.219 \times 1.21 \\
9\end{array}$ & $\begin{array}{l}1.293 \times 0.3 \\
3\end{array}$ \\
\hline Area $\left(m^{2}\right)$ & 1.7424 & 1.485961 & 0.42669 \\
\hline $\begin{array}{l}\text { Normal } \\
\text { operating } \\
\text { cell temp. }\end{array}$ & $44 \mathrm{C}^{0}$ & $28 \mathrm{C}^{\mathrm{O}}$ & $25 \mathrm{C}^{\mathrm{O}}$ \\
\hline $\begin{array}{l}\text { Cell } \\
\text { efficiency }\end{array}$ & $14.2 \%$ & $11 \%$ & $12 \%$ \\
\hline $\begin{array}{l}\text { Module } \\
\text { efficiency }\end{array}$ & $12.2 \%$ & $10 \%$ & $10 \%$ \\
\hline $\begin{array}{l}\text { Module } \\
\text { O.C. } \\
\text { voltage } \\
\left(V_{\text {oc }}\right), \mathrm{V} \\
\text { (dc) }\end{array}$ & $24.5 \mathrm{~V}$ & -------- & 21.6 \\
\hline $\begin{array}{l}\text { Module } \\
\text { S.C. current } \\
\text { (ISC), A }\end{array}$ & 9.52 & -------- & 3.15 \\
\hline $\begin{array}{l}\text { Module } \\
\text { voltage at } \\
\text { max Power } \\
\text { V }\end{array}$ & 19.91 & 120 & 17.5 \\
\hline $\begin{array}{l}\text { Module } \\
\text { current at } \\
\text { max power } \\
(\mathrm{Imp}), \text { A }\end{array}$ & 8.98 & 1.24 & 2.85 \\
\hline $\begin{array}{l}\text { Module } \\
\text { max. power } \\
(\mathrm{Ppm}), \mathrm{W}\end{array}$ & 178.8 & 149 & 50 \\
\hline
\end{tabular}

The following assumptions have been considered:

1- The output of PVPS via an inverter is pure sine wave

2- Small rated IM have been considered as illustrated in table (1)

3- Solar cell types used are tabulated in table (2)

4- The tapping transformer used is an autotransformer type.

\section{EXECUSION OF COMPUTERIZED ALGORITHM}

The solution procedure that used to investigate the case under study is divided according to the above methodology into four stages: The first stage concerns with the design of the required PVPS. The second one is the investigation of energy balance. Whereas the third stage concerns with the $\mathrm{I}-\mathrm{V} \mathrm{C} / \mathrm{C}$ and the last one is concerned with the cost estimation. The different stages can be detailed as follows:

\section{A. Design of PVPS}

The extraterrestrial radiation and the radiation on horizontal surfaces of the selected site represent the data required for the solution. A complete computer program based on the corresponding methodology of PART 1 has been designed and applied.

The obtained results of this program can be summarized as follows:

1- The required $\mathrm{SCA}_{\mathrm{y}}$ to supply the five different types of the IM according to the rated power, voltage, and current has been estimated. Moreover, this program has been executed for the different solar cell types. These results are tabulated in Table (3).

2- On the other hand, the hourly, monthly average and yearly average capacity factors have been obtained.

From Table (3) and Fig. 3 it is concluded that the SCAy needed for each IM type is the same under the same solar cell type. This is because each IM has the same rated power. SCAy differs from solar cell type to another for the same IM. On the other hand, considering the $\mathrm{SCA}_{\mathrm{y}}$ needed, it can be seen that the lowest value of $\mathrm{SCA}_{\mathrm{y}}$ occurs when using the Dentretic-Web Silicon solar cell type. Thus, it is recommended to use this solar cell type in the case of available small land area.

Table 3. The Solar Cells Area and Calculated Number of Modules for Different IM and Solar Cell Types

\begin{tabular}{|l|l|l|l|l|l|l|}
\hline \multirow{2}{*}{$\begin{array}{l}\text { Solar } \\
\text { Type }\end{array}$} & \multicolumn{2}{|c|}{$\begin{array}{c}\text { Dentretic-Web } \\
\text { Silicon }\end{array}$} & \multicolumn{2}{c|}{$\begin{array}{c}\text { Monolithic-Thin- } \\
\text { Film Smorphous }\end{array}$} & \multicolumn{2}{c|}{$\begin{array}{c}\text { M-50 } \\
\text { Silicon Type }\end{array}$} \\
\cline { 2 - 7 } IM Type & Area $\left(\mathrm{m}^{2}\right)$ & No. & Area $\left(\mathrm{m}^{2}\right)$ & No. & $\begin{array}{l}\text { Area } \\
\left(\mathrm{m}^{2}\right)\end{array}$ & $\begin{array}{l}\text { No } \\
.\end{array}$ \\
\hline CRIM & 2.515 & 2 & 3.362 & 3 & 3.374 & 8 \\
\hline SPIM & 2.515 & 2 & 3.362 & 3 & 3.374 & 8 \\
\hline CSIM & 2.515 & 2 & 3.362 & 3 & 3.374 & 8 \\
\hline WRIM & 2.515 & 2 & 3.362 & 3 & 3.374 & 8 \\
\hline SQIM & 2.515 & 2 & 3.362 & 3 & 3.374 & 8 \\
\hline
\end{tabular}

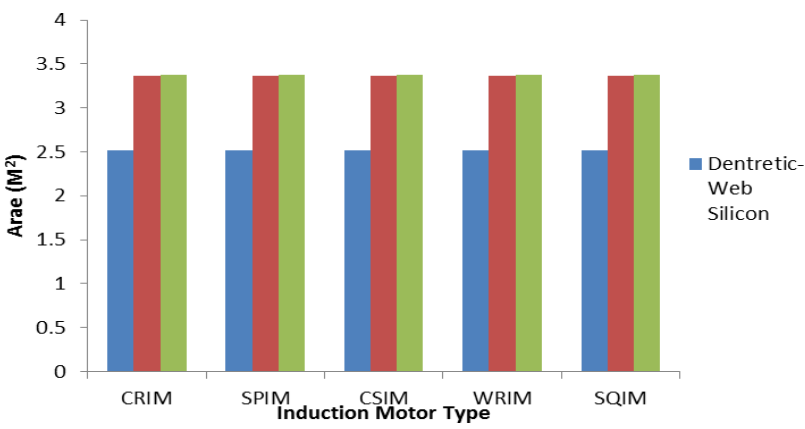

Fig.3. The Needed SCAy of Solar Cell Using Different Types of IM.

Energy Balance Data required:

The required data for this section can be summarized as follows:

a. The ambient temperature.

b. The characteristics of the selected solar cell.

c. The characteristics of the selected IM.

d. The hourly radiation incident on the titled surface calculated at the best tilt angle. 
ISO 9001:2008 Certified

International Journal of Engineering and Innovative Technology (IJEIT)

Volume 10, Issue 2, August 2020

The energy balance problem has been investigated according energy except for the small value when the IM starts at interval hour to the suggested technique based on the methodology explained of (16-17) (not shown in the Figure). Moreover, the maximum in the previous sections. This technique takes into consideration yearly surplus energy occurs when IM starts at hour 9 and operates the various conditions of the IM, such as the ratio of loading during the period between 9-17.

w.r.t. the full load, the starting load ratio w.r.t. the full load and no load conditions. This investigation is necessary to find out the reliability and ability of the designed PVPS/BS to produce the necessary power as well as the current at the different conditions. Thus, the surplus and deficit energy and the optimum number of PV modules required can be determined Fig. 4 shows the complete flowchart of the proposed computer program which was designed and applied.

\section{B. Results}

By the aid of the computer program described in Fig.4, the operation of the IM has been investigated. First, the following definitions are used to make the understanding of the different starting conditions be easier:-

1- Worst condition: in this condition it is assumed that the IM will be started under full load and supply by its rated voltage.

2- Normal condition: it is considered here that the IM will be started under its full load and supplied by the fraction of its rated voltage which makes the value of its starting torque equal to or greater than the full load torque.

3- No load condition:

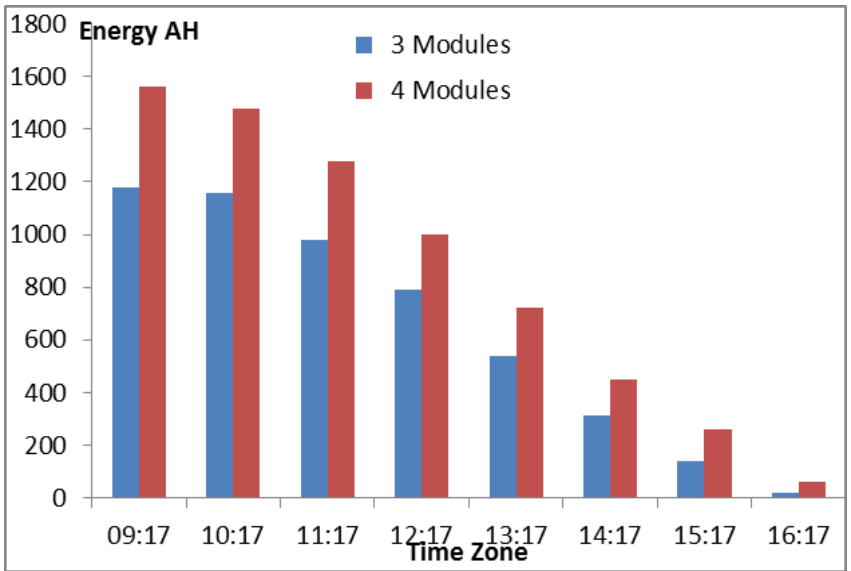

Fig. 5: effect of starting hour on the surplus and deficit energy (using monolithic-Thin Film-Amorphous solar cell type)

\section{The influence of the number of modules on the starting}

\section{hour}

Figure 6 displays the relation between energy and number of modules under different starting hours (case of SQIM and Monolithic-Thin film-Amorphous solar cell type). This figure

a- Starting of IM at no load and supplied with 50\% shows that the IM can be started at any hour from 9 to 15 without of its rated load.

deficit energy by using three modules only. On the other hand, four

b- Starting of IM at no load and supplied with $25 \%$ modules must be used to start the run of IM at hour of 16 without of its rated voltage.

deficit. It must be mentioned here that the above results are obtained

According to the calculated number of modules, shown in for all the IM types used and for the different types of selected solar table 3, the generated power is calculated. Then, the surplus and cells. Above results are obtained for all the IM types used and for deficit energy along the operating day hours (from 9 AM to 17) the different types of selected solar cells.

are estimated. To overcome the problem of the starting period, when the required current is about 5 to 8 times of the rated current, the actual number of modules is recalculated. After the starting period the surplus energy is directed to the BS.

The energy balance study, here, has been made to obtain the optimum number of modules which reduces the effect of the previous conditions. Using the number of modules of a certain solar cell type obtained as a result of the energy balance program, makes us run the IM of certain type under any condition. Tables (5-8) illustrate the number of modules needed for each IM type using different types of solar cell under the previous conditions. From this Table it can be seen that each IM type has the same number of modules for the same solar cell type without any consideration of the previous conditions. Thus, our aim is achieved. This is true for all cases except the case of SQIM when using Monolithic-Thin film-Amorphous solar cell under the worst \& the no load with $50 \%$ rated voltage conditions.

1. Effect of the starting hour and the operating period on the yearly surplus and deficit energy:

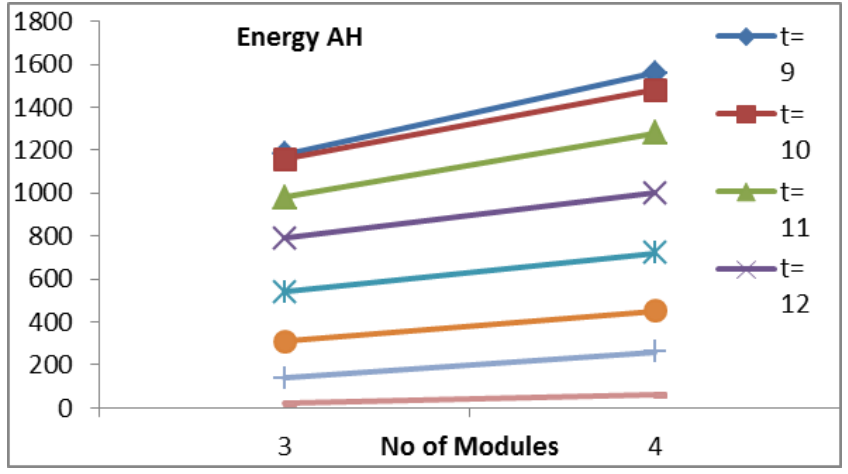

Fig. 6: Relation between energy and number of modules needed under different starting hours. (Case of SQIM and monolithicThin Film-Amorphous solar cell type)

\section{I-V Characteristics $(\mathrm{C} / \mathrm{C})$}

The radiation on the tilted surface, ambient temperature, and the used solar cells etc. represent the data required for this part. A computer program has been designed and applied to develop the I-V $\mathrm{C} / \mathrm{C}$ of the PVPS. The $\mathrm{I}-\mathrm{V} \mathrm{C} / \mathrm{C}$ has been determined for the different selected solar cell types. Figure (8) shows the I-V C/C for SQIM using four modules of Monolithic-Thin Film-Amorphous solar cell type (summer season, July). This figure displays the maximum power points at different dy hours.

The line which passes through these points represents the load line. The IM must be operated following this line to take the maximum power produced from the PVPS. Table (40 shows the 
ISO 9001:2008 Certified

International Journal of Engineering and Innovative Technology (IJEIT)

Volume 10, Issue 2, August 2020

maximum power supplied from the PVPS of monolithic-Thin Film-Amorphous solar cell type for the different types of IM under the worst condition during the summer season in July. From this table, it is seen that the voltage, current and power at the maximum power point have suitable values for running single-phase and three-phase IM directly at certain hours or by using a conventional tapping transformer through a suitable PCU.

There are other Figures and Tables for the other two selected solar cell types. Comparative study between the $\mathrm{I}-\mathrm{V} \mathrm{C} / \mathrm{Cs}$ of monolithic thin film amorphous, M-50 and denetric web solar cell types has been carried out. From this study it can be concluded that the I-V C/Cs of monolithic thin film amorphous solar cell type has the most technical parameters to be used in constructing PVPS to supply IM.

\section{Cost Estimation}

The data required for this part are the SCAy, land area factor (LF), rating of the PCU, the price per square meter of solar cell, land price $(\mathrm{BC}, \$ / \mathrm{kWh})$, field controlling and building cost $(\mathrm{FC})$, rate of interest ${ }^{\circledR}$, life period $(\mathrm{n})$, and the yearly generated energy.

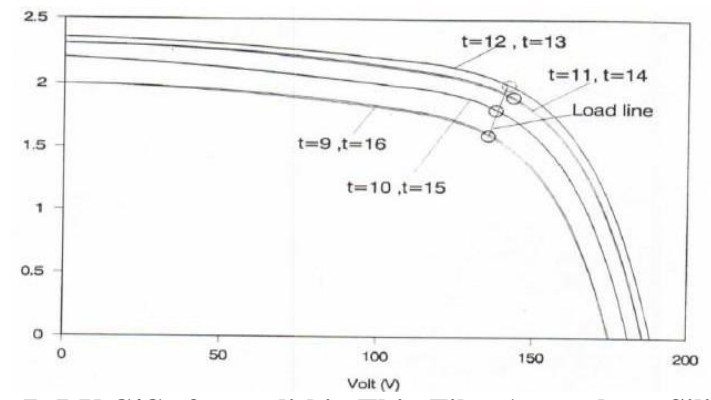

Fig 7: I-V C/C of monolithic-Thin Film-Amorphous Silicon PVPS constructed to supply SQIM under Worst condition (summer season, July)

The ECF in Cent/kWh generated by PVPS has been estimated under the following cases:

1- $\quad$ Five selected IM.

2- $\quad$ Three selected solar cell types. 3- Four starting conditions.

During the computation of ECF under the above cases, it is noticed that there are two factors which affect it. These factors are the BS rating and the yearly generated energy. The obtained results are tabulated in Tables (5), (6), (7) and (8). From these Tables it is concluded that:

1- Monolithic- thin film Amorphous PVPS is the most economic one to feed CRIM (1-phase), WRIM (3-phase) and SQIM (3-phase) under worst condition. This is also true under normal condition except for SQIM. Also this PVPS type has the same advantages to supply CRIM under the other two conditions.

2- Denetritic-web silicon PVPS is the most suitable type from the economical point of view to supply SPIM (1-phase) and CSIM (1-phase) under all starting conditions. This is also true for the studied SQIM (3-phase).

PVPS type represents the most economical type to feed studied WRIM (3-phase) under no load (50\% of rated voltage) and worst conditions. Considering the $\mathrm{I}-\mathrm{V} \mathrm{C} / \mathrm{C}$ which was studied in section (4.3.2), it is recommended to use Monolithicthin film amorphous PVPS instead of Denetritic-web silicon PVPS. This is because of its suitable technical parameters. Moreover, from Tables (5), (6), (7) and (8), it is seen that the ECF of PVPS using Monolithicthin film-Amorphous solar cell has a value which is approximately corresponding to its value of PVPS using Dentritic-web silicon.

3- It is not recommended to use M-50 PVPS because of its high ECF and its $\mathrm{I}-\mathrm{V} \mathrm{C} / \mathrm{C}$ has a poor technical parameter.

\section{CONCLUSION}

The following conclusions can be obtained:-

1- $\quad$ The studied IM can be started at any hour from 9 to 15 without deficit energy by using three modules only. On the other hand, four modules must be used to start the studied IM at hour 16 without deficit.

2- $\quad$ The PVPS voltage, current and power at the maximum power point have suitable values for running studied single-phase and three-phase IM directly at certain hours or by using a conventional tapping transformer through a suitable PCU.

3- $\quad$ The I-V C/Cs of monolithic thin film amorphous solar cell type has the most suitable technical parameters to be used in constructing PVPS to supply studied IM and this type is the most economic one to feed studied CRIM (1-phase), studied WRIM (3phase) and studied SQIM (3-phase) under worst condition. This is also true under normal condition except for studied SQIM. Also this PVPS type has the same advantages to supply studied CRIM under the other two conditions.

4- Dentritic-web silicon PVPS is the most suitable system from the economical point of view to supply the studied SPIM (1phase) and studied CSIM (1-phase) under all starting conditions. This is also true for studied SQIM (3-phase) under normal and no load conditions. This PVPS type represents the most economic system to feed the studied WRIM (3-phase) under normal (50\% of rated voltage) and worst case conditions.

5- It is not recommended to use M-50 PVPS because of its high ECF and poor technical parameters.

\section{REFERENCES}

1] D.S.H. Chan, "Analytical methods for the extraction of solar-cell single- and double-diode model parameters from I-V characteristics", IEEE Transactions on Electron Devices, Volume: 34, Issue: 2 Feb 1987

[2] Green MA, Emery K, Hishikawa Y, Warta W, Dunlop ED, "Solar cell efficiency tables (Version 39)",Progress in Photovoltaic's: Research and Applications 2012; 20: 12 20Online Library Web of Science Google Scholar.

[3] Green MA, Emery K, Hishikawa Y, Warta W,"Solar cell efficiency tables (Version 33)", Progress in Photovoltaic's: Research and Applications 2009; 17: 85-94.Wiley Online Library CAS Web of Science Google Scholar.

[4] M.Abdolzadehab M.Amer, "Improving the effectiveness of a photovoltaic water pumping system by spraying water over the front of photovoltaic cells", Journal of Renewable Energy, Volume 34, Issue 1, January 2009, PP. 91-96. 
ISSN: 2277-3754

ISO 9001:2008 Certified

International Journal of Engineering and Innovative Technology (IJEIT)

Volume 10, Issue 2, August 2020

[5] J. Cruz-Colon, R. Otero-De-Leon, Eduardo I. Ortiz-Rivera, "Three phase induction motor drive using fly back converter and PWM inverter fed from a single photovoltaic panel", IEEE Conference 2011.

[6] A. Al-Diab, C. Sourkounis, "Variable step size P\&O MPPT algorithm for PV systems", Optimization of Electrical and Electronic Equipment (OPTIM) 2010 12th International Conference on, 20-22 May 2010, pp. 10971102 .

APPENDIX

Table 4.Maximum Power Of Monolithic-Thin Film-Amorphous Silicon PVPS to Supply IM Through PCU and Tapping Transformer (Worst Condition, Summer Season, July)

\begin{tabular}{|c|c|c|c|c|c|c|c|c|c|c|c|c|c|c|c|}
\hline \multicolumn{4}{|c|}{\begin{tabular}{|l|l|} 
IM type & $\begin{array}{l}\text { CRIM } \\
\text { (5-Mod.) }\end{array}$ \\
\end{tabular}} & \multicolumn{3}{|c|}{$\begin{array}{l}\text { SPIM } \\
\text { (8-Mod.) }\end{array}$} & \multicolumn{3}{|c|}{$\begin{array}{l}\text { CSIM } \\
\text { (8-Mod.) }\end{array}$} & \multicolumn{3}{|c|}{$\begin{array}{l}\text { WRIM } \\
\text { (4-Mod.) }\end{array}$} & \multicolumn{3}{|c|}{$\begin{array}{l}\text { SQIM } \\
\text { (4-Mod) }\end{array}$} \\
\hline & $\begin{array}{l}\text { Ipm } \\
\text { (A) }\end{array}$ & $\begin{array}{l}\text { Vpm } \\
(\mathrm{V})\end{array}$ & $\begin{array}{l}\text { Ppm } \\
(\mathrm{W})\end{array}$ & $\begin{array}{l}\text { Ipm } \\
\text { (A) }\end{array}$ & $\begin{array}{l}\text { Vpm } \\
(\mathrm{V})\end{array}$ & $\begin{array}{l}\text { Ppm } \\
(\mathrm{W})\end{array}$ & $\begin{array}{l}\text { Ipm } \\
\text { (A) }\end{array}$ & $\begin{array}{l}\text { Vpm } \\
(\mathrm{V})\end{array}$ & $\begin{array}{l}\text { Ppm } \\
(\mathrm{W})\end{array}$ & $\begin{array}{l}\text { Ipm } \\
\text { (A) }\end{array}$ & $\begin{array}{l}\text { Vpm } \\
\text { (V) }\end{array}$ & $\begin{array}{l}\text { Ppm } \\
(\mathrm{W})\end{array}$ & $\begin{array}{l}\text { Ipm } \\
\text { (A) }\end{array}$ & $\begin{array}{l}\mathrm{Vpm} \\
(\mathrm{V})\end{array}$ & $\begin{array}{l}\text { Ppm } \\
(\mathrm{W})\end{array}$ \\
\hline 9 & 1.7 & 211.8 & 360.1 & 1.7 & 600.5 & 1021 & 1.7 & 600.5 & 1021 & 1.6 & 135.6 & 217.0 & 1.6 & 135.6 & 217.0 \\
\hline$\overline{10}$ & 1.8 & 228.9 & 412.1 & 1.9 & 564.7 & 1129 & 1.9 & 564.7 & 1129 & 1.8 & 138.0 & 248.3 & 1.8 & 138.0 & 248.3 \\
\hline 11 & 2.0 & 225.7 & 451.3 & 2.0 & 639.5 & 1279 & 2.0 & 639.5 & 1279 & 1.9 & 143.5 & 272.7 & 1.9 & 143.5 & 272.7 \\
\hline$\overline{12}$ & 2.0 & 236.3 & 472.5 & 2.1 & 637.2 & 1338 & 2.1 & 637.2 & 1338 & 2.0 & 142.1 & 284.1 & 2.0 & 142.1 & 284.1 \\
\hline 13 & 2.0 & 236.0 & 471.9 & 2.1 & 636.3 & 1336 & 2.1 & 636.3 & 1336 & 2.0 & 141.8 & 283.6 & 2.0 & 141.8 & 283.6 \\
\hline$\overline{14}$ & 1.9 & 236.1 & 448.6 & 2.0 & 636.2 & 1272 & 2.0 & 636.2 & 1272 & 1.9 & 142.6 & 270.9 & 1.9 & 142.6 & 270.9 \\
\hline 15 & 1,8 & 229.4 & 412.9 & 1.9 & 616.9 & 1172 & 1.9 & 616.9 & 1172 & 1.8 & 138.3 & 248.9 & 1.8 & 138.3 & 248.9 \\
\hline 16 & 1.7 & 213.7 & 363.3 & 1.7 & 604.0 & 1027 & 1.7 & 604.0 & 1027 & 1.6 & 136.6 & 218.5 & 1.6 & 136.6 & 218.5 \\
\hline
\end{tabular}

Table 5. The ECF for five types of IM with three types of Solar cell under W. C.

\begin{tabular}{|c|c|c|c|c|c|c|c|c|c|c|c|c|c|c|c|}
\hline Case of & \multicolumn{15}{|c|}{ Starting under full load (Worst Condition) } \\
\hline Motor & \multicolumn{3}{|c|}{ CRIM } & \multicolumn{3}{|c|}{ SPIM } & \multicolumn{3}{|c|}{ CSIM } & \multicolumn{3}{|c|}{ WRIM } & \multicolumn{3}{|c|}{ SqIM } \\
\hline $\begin{array}{l}\text { Cell } \\
\text { type }\end{array}$ & DW & MT & M50 & DW & MT & M50 & DW & MT & M50 & DW & MT & M50 & DW & MT & M50 \\
\hline $\begin{array}{l}\text { No of } \\
\text { mod. }\end{array}$ & 4 & 5 & 13 & 7 & 8 & 22 & 7 & 8 & 22 & 3 & 4 & 10 & 3 & 4 & 9 \\
\hline $\begin{array}{l}\mathrm{ECF} \\
(\mathrm{c} / \mathrm{kWh})\end{array}$ & 2.87 & 2.76 & 3.20 & 1.67 & 1.72 & 1.89 & 1.64 & 1.72 & 1.89 & 3.82 & 3.4 & 4.1 & 3.8 & 3.4 & 4.6 \\
\hline
\end{tabular}

Table 6. The ECF for five types of IM with three types of Solar cell under N. C.

\begin{tabular}{|l|l|l|l|l|l|l|l|l|l|l|l|l|l|l|l|}
\hline $\begin{array}{l}\text { Case of } \\
\text { operation }\end{array}$ & \multicolumn{9}{l|}{ Starting under full load (Worst Condition) } \\
\hline Motor type & CRIM & \multicolumn{10}{l|}{ SPIM } & \multicolumn{1}{l|}{ CSIM } & \multicolumn{2}{l|}{ WRIM } & \multicolumn{2}{l|}{ SqIM } \\
\hline Cell type & DW & MT & M50 & DW & MT & M50 & DW & MT & M50 & DW & MT & M50 & DW & MT & M50 \\
\hline No of mod. & 4 & 5 & 13 & 7 & 8 & 22 & 7 & 8 & 22 & 3 & 4 & 10 & 3 & 3 & 9 \\
\hline $\begin{array}{l}\text { ECF } \\
\text { (c/kWh) }\end{array}$ & 2.87 & 2.76 & 3.18 & 1.64 & 1.72 & 1.89 & 1.64 & 1.72 & 1.89 & 3.83 & 3.44 & 4.13 & 3.83 & 3.59 & 4.59 \\
\hline
\end{tabular}

Table 7. The ECF for five types of IM with three types of Solar cell under F. C.

\begin{tabular}{|l|l|l|l|l|l|l|l|l|l|l|l|l|l|l|l|}
\hline $\begin{array}{l}\text { Case of } \\
\text { operation }\end{array}$ & \multicolumn{10}{l|}{ Starting under full load (Worst Condition) } \\
\hline Motor type & CRIM & \multicolumn{10}{l|}{ SPIM } & \multicolumn{1}{l|}{ CSIM } & \multicolumn{2}{l|}{ WRIM } & SqIM \\
\hline Cell type & DW & MT & M50 & DW & MT & M50 & DW & MT & M50 & DW & MT & M50 & DW & MT & M50 \\
\hline No of mod. & 4 & 5 & 13 & 7 & 8 & 22 & 7 & 8 & 22 & 3 & 4 & 10 & 3 & 4 & 9 \\
\hline $\begin{array}{l}\text { ECF } \\
\text { (c/kWh) }\end{array}$ & 2.87 & 2.76 & 3.20 & 1.67 & 1.72 & 1.89 & 1.64 & 1.72 & 1.89 & 3.82 & 3.4 & 4.1 & 3.8 & 4.6 & 4.6 \\
\hline
\end{tabular}

Table 8. The ECF for five types of IM with three types of solar cell under S.C.

\begin{tabular}{|c|c|c|c|c|c|c|c|c|c|c|c|c|c|c|c|}
\hline Case of & \multicolumn{15}{|c|}{ Starting under full load (Worst Condition) } \\
\hline Motor type & \multicolumn{3}{|c|}{ CRIM } & \multicolumn{3}{|c|}{ SPIM } & \multicolumn{3}{|c|}{ CSIM } & \multicolumn{3}{|c|}{ WRIM } & \multicolumn{3}{|c|}{ SqIM } \\
\hline Cell type & DW & MT & M50 & DW & MT & M50 & DW & MT & M50 & DW & MT & M50 & DW & MT & $\begin{array}{l}\text { M5 } \\
0\end{array}$ \\
\hline No of mod. & 4 & 5 & 13 & 7 & 8 & 22 & 7 & 8 & 22 & 3 & 4 & 10 & 3 & 3 & 9 \\
\hline $\begin{array}{l}\text { ECF } \\
\text { (c/kWh) }\end{array}$ & 2.87 & 2.76 & 3.18 & 1.64 & 1.72 & 1.89 & 1.64 & 1.72 & 1.89 & 3.83 & 3.44 & 4.13 & $\begin{array}{l}3.8 \\
3\end{array}$ & $\begin{array}{l}3.5 \\
9\end{array}$ & 4.59 \\
\hline
\end{tabular}

$\mathrm{N}$ : is the starting current / IM rated current, $\mathrm{M}$ is the number of module, $\mathrm{V}_{\mathrm{pv}}$ is the module voltage, VRo is the IM rated voltage. 